\title{
Autotaxin: Its Role in Biology of Melanoma Cells and as a Pharmacological Target
}

\author{
Maciej Jankowski ${ }^{1,2}$ \\ ${ }^{1}$ Department of Therapy Monitoring and Pharmacogenetics, Medical University of Gdansk, Debinki 7, 80-211 Gdańsk, Poland \\ ${ }^{2}$ Laboratory of Molecular and Cellular Nephrology, Mossakowski Medical Research Center, Polish Academy of Sciences, \\ 80-211 Gdańsk, Poland
}

Correspondence should be addressed to Maciej Jankowski, majank@gumed.edu.pl

Received 29 August 2010; Accepted 12 January 2011

Academic Editor: Jun-Mo Yang

Copyright ( 2011 Maciej Jankowski. This is an open access article distributed under the Creative Commons Attribution License, which permits unrestricted use, distribution, and reproduction in any medium, provided the original work is properly cited.

\begin{abstract}
Autotaxin (ATX) is an extracellular lysophospholipase D (lysoPLD) released from normal cells and cancer cells. Activity of ATX is detected in various biological fluids. The lysophosphatidic acid (LPA) is the main product of ATX. LPA acting through specific G protein-coupled receptors $\left(\mathrm{LPA}_{1}-\mathrm{LPA}_{6}\right)$ affects immunological response, normal development, and malignant tumors' formation and progression. In this review, the impact of autotoxin on biology of melanoma cells and potential treatment is discussed.
\end{abstract}

\section{Biochemistry and Structure of Autotoxin}

Autotaxin, ATX (E.C. 3.1.4.39), is a member of the family of nucleotide pyrophosphatases/phosphodiesterase (NPP1-7) and is also referred, as NPP2 [1]. It is to a glycoprotein with four possible $\mathrm{N}$-glycosylation sites, synthesized as a preproenzyme and is secreted to extracellular space following two $\mathrm{N}$-terminal cleavages (27 and 8 amino acids) [2, 3]. ATX is a constitutively active enzyme possessing activity of phospholipase D. It hydrolyzes the head groups of lysophospholipids to lysophosphatidic acid (1 or 2-acylsn-glycerol-3-phosphate, LPA) and also acts on sphingosylphosphorylcholine to produce sphingosine 1-phosphate (S1P) $[4,5]$. Both, LPA and S1P are strong inhibitors of ATX with affinity to enzyme approximately 1000-fold higher than reported for ATX substrates [6]. mRNA for ATX has been detected in brain, ovary, lung intestine, and kidney but enzyme activity has been detected in blood, cerebrospinal and seminal fluid, urine, and saliva [7-11]. It is not filtered in the glomerulus because of high molecular weight $(\sim 125 \mathrm{kDa})$ but is cleared from the circulation by the scavenger receptors of liver sinusoidal endothelial cells [12]. Moreover, ATX is the main source of blood LPA $(\sim 0.1 \mu \mathrm{M}$ plasma and $\sim 1 \mu \mathrm{M}$ serum), however, not for S1P $[13,14]$. There is evidence that S1P is produced intracellularly via sphingosine kinases and transported through ATP-binding cassette transporter $[15,16]$. ATX hydrolyzes also ATP; however, affinity to ATP is at least 50-fold lower then for lysophospholipids [17, 18]. LPA acts on target cells through specific G-protein-coupled receptors: $\mathrm{LPA}_{1} / \mathrm{Edg} 2$, $\mathrm{LPA}_{2} / \mathrm{Edg} 4, \mathrm{LPA}_{3} / \mathrm{Edg} 7, \mathrm{LPA}_{4} / \mathrm{GPR} 23 / \mathrm{P} 2 \mathrm{Y}_{9}, \mathrm{LPA}_{5} / \mathrm{GPR} 92$, $\mathrm{LPA}_{6} / \mathrm{P}_{2} \mathrm{Y}_{5}$ broadly expressed in normal and cancer cells $[19,20]$. The LPA-binding proteins for example, albumin, determine the activation of the specific LPA receptors; $\mathrm{LPA}_{3}$, in contrast to $\mathrm{LPA}_{1}$ and $\mathrm{LPA}_{2}$, is not activated by complex LPA-albumin [21].

The structure of autotoxin is presented in Figure 1. At the N-terminus, ATX possesses hydrophobic signal sequence (SS) followed by two somatomedin B-like domains (SBLD) with RGD tripeptide motif suggesting that this domain may play a role in cell-extracellular matrix interactions. At catalytic domain (CD), $\mathrm{Thr}^{210}$ and N542-linked glycan are suggested to be responsible for hydrolytic activity of ATX, but motif G/FXGXXG is responsible for metal binding. ATX activity is stimulated by divalent cations for example, $\mathrm{Ca}^{2+}, \mathrm{Mg}^{2+}$, and $\mathrm{Co}^{2+}$. C-terminally to $\mathrm{CD}$ is the nucleaselike domain (NLD). It contains EF-hand-like motif and is structurally similar to DNA and RNA-nonspecific endonucleases; however, it lacks the catalytic activity. In humans, NLD is covalently linked with catalytic domain via disulfide 


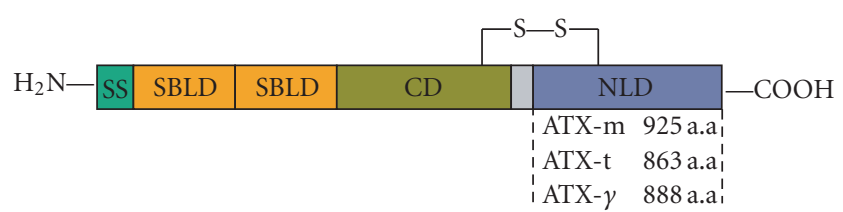

Figure 1: Scheme of the structure domains of autotaxin isoforms. SS: signal sequence, SBLD: somatomedin B-like domains, CD: catalytic domain, NLD: nuclease-like domain.

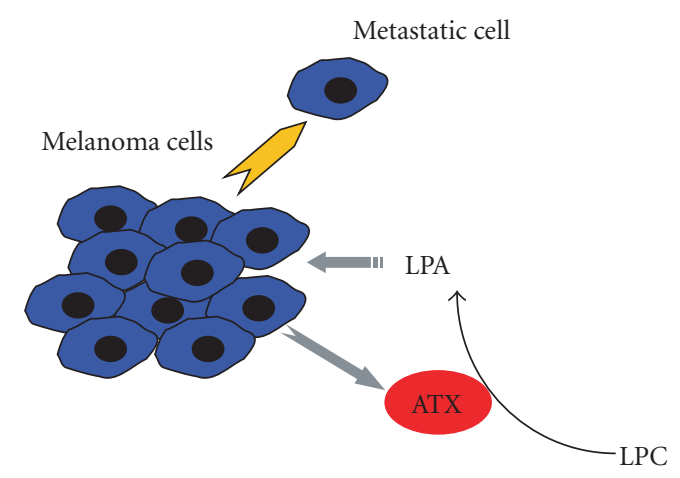

FIGURE 2: Role of ATX-LPA axis in motility of melanoma cells. ATX: autotaxin, LPA: lysophosphatidic acid, and LPC: lysophospholipids.

bridge (C413-C805). The ATX gene is located on chromosome 8 at position $8 \mathrm{q} 24.1$ and ATX has three alternative splicing isoforms in humans: ATX teratocarcinoma-derived ATX-t (925 a.a); melanoma-derived ATX-m (863 a.a), and brain specific, ATX- $\gamma$ (888 a.a) [22-25].

\section{Role of Autotoxin during Normal Development}

ATX has a critical role in formation of vasculature by vasculogenesis and angiogenesis. ATX knockout mice $\left(\mathrm{atx}^{-/-}\right)$ are lethal around embryonic day 10.5. Admittedly, ATX is a major producing enzyme for LPA, nevertheless the phenotypes of LPA receptors knockout mice is less severe, suggesting that ATX-induced cellular signal may involve others pathways. This speculation is supported by results of experiments where modification of LPA level in blood (2fold increase) by driving ATX expression is not sufficient to induce tumorigenesis [13, 26-28].

\section{Role of Autotoxin in Biology of Melanoma Cells}

ATX was identified in the cultured cell supernatant of human melanoma cells (A2058) as a cell motility-stimulating factor acting at $\mathrm{pM}-\mathrm{nM}$ concentrations in pertussis toxin-sensitive manner [29]. Further studies have provided evidence that LPA, product of ATX, mediates chemotaxis and proliferation of melanoma cells [30]. The recent experiments suggest that ATX expression is one of the factors involved in metastasis of melanoma cells (Figure 2). Inhibition of ATX production blocks LPA-induced migration of melanoma cells [31]. It has been detected that melanoma metastatic specimens have increased ATX level, and ATX expression in primary melanoma is higher than in melanoma in situ [32]. Moreover, reduced expression of ATX predicts survival in uveal melanoma [33].

It has been shown that ATX-stimulated motility is suppressed by an $\mathrm{LPA}_{1}$-selective antagonist, Ki16425, in melanoma cells [34]. Accumulating evidence suggest the various intracellular signaling pathways may be involved in ATX-induced motility of melanoma cell. It has been shown that this action is mediated through G-protein coupled isoform of phosphatidylinositol 3-kinase $\gamma(\mathrm{PI} 3 \mathrm{~K} \gamma)$ suggesting involvement of proteins located downstream of PI3K $\gamma$, for example, small $\mathrm{G}$ proteins [35]. Accordingly, there is evidence that ATX induces Cdc42/Rac1/p21-activated kinase (PAK1) complex formation [36]. The experimental data suggest that this complex is required for LPA-induced activation of focal adhesion kinase (FAK) [37]. The changes of PAK1 and FAK activity affect cytoskeleton proteins and structural integrity of melanoma cells. Moreover, ATX in melanoma cells induces the expression and activity of urokinase-type plasminogen activator (UPA) in a dosedependent manner. This action is mediated by $\mathrm{G}_{\mathrm{i}}$ proteins and PI3K/Akt signaling involving translocation of p65 into the nucleus and DNA binding of necrosis factor kappa B [38]. In general, action of LPA on melanoma cells enhances their metastaic potential (Figure 3). Recent experiments have provided evidence about the role of LPA receptors in biology of melanoma cells [32]. Downregulation of $\mathrm{LPA}_{3}$ and using sequence-specific small interfering RNA (siRNA) reduces melanoma cells viability and proliferation. The effects of LPA receptors activation in melanoma cells are presented in Figure 4.

\section{Autotoxin as a Pharmacological Target}

The approved melanoma therapy lacks significant efficiency, hence, new therapeutic targets are under investigation. The current research focuses on the autotoxin-LPA axis [39]. Because LPA acts on multiple receptors with overlapping activities, currently the LPA receptors are not attractive as a pharmacological target, and the main stream of investigation concerns ATX activity.

4.1. L-Histidine. L-histidine inhibits activities of ATX in a non-competitive manner with $\mathrm{IC}_{50} \sim 4 \mathrm{mM}$ and ATXstimulated migration of human melanoma cells; $10 \mathrm{mM}$ L-histidine induces $90 \%-95 \%$ reduction in stimulated motility. The proposed mechanism of L-histidine action is based on inhibition of a process that is required for the hydrolysis of both nucleotides and phospholipids [40].

4.2. Analogs of Bioactive Lipids. ATX is negatively regulated by LPA. The effect is dependent on the length of the acyl chain; maximal inhibition is induced by 1-oleoyl-LPA ( IC $\left._{50} \sim 0.1-2 \mu \mathrm{M}\right), 1$-palmitoyl-LPA, and 1-myristoyl-LPA whereas short-chain LPA $(6: 0)$ has no measurable effect. The inhibition of ATX activity results from a combination 


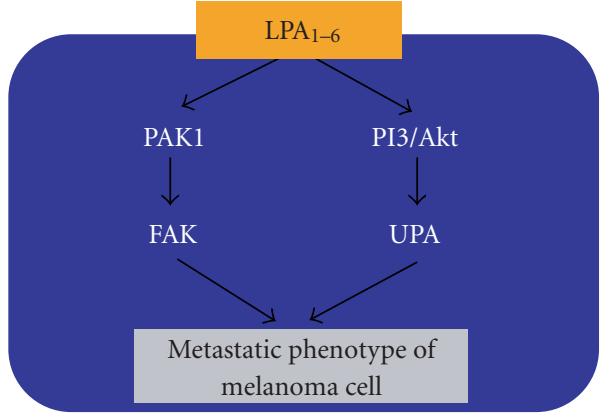

FIgURE 3: A proposal role for LPA receptors during melanoma progression. LPA receptors activation in melanoma cells leads to p21-activated kinase (PAK) and focal adhesion kinase (FAK) and to the activation of phosphoinositide 3-kinase/Akt-kinase and urokinase-type plasminogen activator (UPA). Finally, the melanoma cells express the metastatic phenotype.

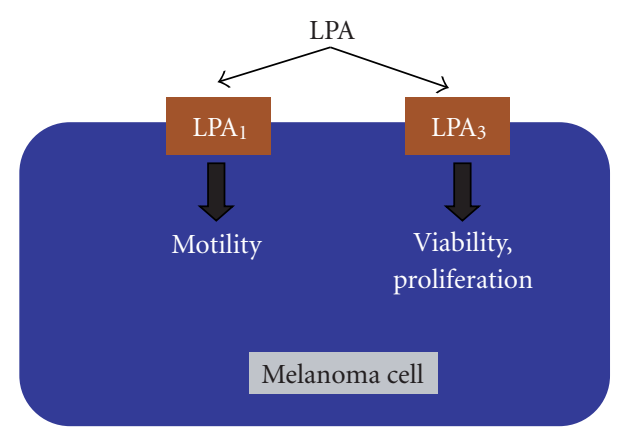

Figure 4: The $\mathrm{LPA}_{1}$ and $\mathrm{LPA}_{3}$ receptors as a potential target for pharmacological intervention.

of a decreased turnover number and decreased affinity of the active site for its substrates. Of note, LPA both inhibits ATX and activates LPA receptors $\left(\mathrm{EC}_{50}\right.$ for LPA 18:1 at $\mathrm{LPA}_{1-4} \sim$ $0.007-0.5 \mu \mathrm{M})$, therefore it may induce the opposite of the intended effect $[6,41]$.

The other group of ATX inhibitors are analogues of cyclic phosphatic acid (1-acyl-sn-glycero-2,3-cyclic-phosphate, cPA) [42, 43]. The naturally occurring cPA, 1-oleoyl-snglycero-2,3-cyclic-phosphate (cPA 18:1) possesses unique properties having two targets: enzyme and receptor. cPA 18:1 inhibits ATX activity with a maximum of $22 \%$ at $1 \mu \mathrm{M}$ and inhibits signaling pathway mediated through $\mathrm{LPA}_{1}$ and $\mathrm{LPA}_{3}$ receptors. Because of this properties, cPA 18:1 is described as having a "one-two punch" [44]. Another naturally occurring cPA, cPA 16:1 (1-palmitoleoyl-snglycero-2,3-cyclic-phosphate) possesses similar activity against ATX with maximum of $45 \%$ at $1 \mu \mathrm{M}$.

Interestingly, replacement of either the $s n-2$ or $s n-3$ oxygen by methylene (carba group) increases the inhibitory properties of these analogues (carba analogues, ccPA) [45]. 2ccPA 16:1 and 2cPA 18:1 (replacement of sn-2 oxygen with a methylene group) inhibit ATX activity about 90\% with $\mathrm{IC}_{50} \sim 140 \mathrm{nM}$ and $\sim 370 \mathrm{nM}$, respectively. Furthermore, $3 c c P A ~ 16: 1$ and 3ccPA 18:1 (replacement of $s n-3$ oxygen with methylene group) inhibit ATX activity about 70\% with $\mathrm{IC}_{50} \sim 300 \mathrm{nM}$ and $\sim 60 \mathrm{nM}$, respectively. Moreover, $3 \mathrm{ccPA}$ does not interact with LPA receptors. The invasion assay using melanoma cells (A2058) has provided evidence that ccPA-induced inhibition of ATX activity results in inhibition of cell migration. Furthermore, $\mathrm{cPA}$ and ccPA exert an inhibitory effect on experimental pulmonary metastasis in mice. Recently, a new generation of ccPA with potential therapeutic modality has been developed. Thio-ccPA 18:1 possesses multitarget properties. It inhibits ATX activity $(\sim 90 \%$ at $10 \mu \mathrm{M})$ and blocks $\mathrm{LPA}_{1}\left(\mathrm{IC}_{50} \sim 800 \mathrm{nM}\right)$ and $\mathrm{LPA}_{3}\left(\mathrm{IC}_{50} \sim 440 \mathrm{nM}\right)$ receptors without effect on $\mathrm{LPA}_{2}$ receptors. Thio-ccPA influences metastatic melanoma tumors in vivo, reducing the number of pulmonary metastases and metastatic lesions to kidney, liver, pancreas, and intestines [32].

4.3. Nonlipid Small Molecule. It has been recently shown that thiazolidinediones compounds with incorporated boric acid moiety into catalic T210 residue (HA 130) inhibit ATX-mediated LPA production with $\mathrm{IC}_{50} \sim 30 \mathrm{nM}$ [46]. Intravenous injection of HA 130 decreases 3.8-fold plasma LPA level in mice at $10 \mathrm{~min}$. Furthermore, HA 130 inhibits ATX-mediated melanoma cells migration without affecting LPA receptor signaling pathways.

A report has been recently published describing the pharmacokinetic and pharmacodynamic properties of PF8380 [47]. It inhibits activity of isolated ATX or ATX activity in blood with $\mathrm{IC}_{50} \sim 3$ and $100 \mathrm{nM}$, respectively. There are no data about influence on melanoma cells, hoverer, PF-8380 $(30 \mathrm{mg} / \mathrm{kg}$ ) taken orally decreases the plasma LPA level about 95\%, suggesting its potential usage in melanoma treatment.

There are several small-molecule, nonlipid ATX inhibitors including hexachlorophene, merbromin, bithionol, and others under investigation [48, 49]. Their mechanism of action differ (competitive, noncompetitive or mixed inhibition) and the most potent compounds inhibit ATX activity with $\mathrm{IC}_{50}$ at micromolar range. Their biological action was confirmed in experiments in vivo measuring effects on melanoma cell motility and invasion. A recently developed new TX autotaxin inhibitor pipemidic acid inhibits ATX with $\mathrm{IC}_{50} \sim 900 \mathrm{nM}$ [50]. The natural phenolic antioxidants, including flavonols, possess inhibitory properties against ATX; however, the effect on ATX activity is about 2-fold lower than LPA 16:1 (1-palmitoleoyl-sn-glycerol-3phosphate). Moreover, it has been estimated that it would be difficult to affect ATX activity in vivo by flavonoids supplementation in diet because plasma concentration of flavonoids in plasma may reach $10 \mu \mathrm{M}$ [51].

The recently published crystallography results are used in ligand-based computational approaches for optimization of the current ATX inhibitors and development of new ones $[52,53]$.

Taken together, the increasing incidence of melanoma and poor average survival of metastatic melanoma are the main reason for the development of the new chemical compounds used in melanoma treatment. Autotaxin, melanoma cell motility-stimulating factor, and their receptors seem to be promising targets for pharmacological treatment 
of melanoma. Much more research is needed for synthesis and pharmacological characterization of new specific ATX or LPA receptors inhibitors.

\section{References}

[1] C. Stefan, S. Jansen, and M. Bollen, "NPP-type ectophosphodiesterases: unity in diversity," Trends in Biochemical Sciences, vol. 30, no. 10, pp. 542-550, 2005.

[2] M. L. Stracke, A. Arestad, M. Levine, H. C. Krutzsch, and L. A. Liotta, "Autotaxin is an N-linked glycoprotein but the sugar moieties are not needed for its stimulation of cellular motility," Melanoma Research, vol. 5, no. 4, pp. 203-209, 1995.

[3] S. Jansen, C. Stefan, J. W. M. Creemers et al., "Proteolytic maturation and activation of autotaxin (NPP2), a secreted metastasis-enhancing lysophospholipase D," Journal of Cell Science, vol. 118, no. 14, pp. 3081-3089, 2005.

[4] L. M. Yuelling and B. Fuss, "Autotaxin (ATX): a multifunctional and multi-modular protein possessing enzymatic lysoPLD activity and matricellular properties," Biochimica et Biophysica Acta, vol. 1781, no. 9, pp. 525-530, 2008.

[5] K. Nakanaga, K. Hama, and J. Aoki, "Autotaxin-An LPA producing enzyme with diverse functions," Journal of Biochemistry, vol. 148, no. 1, pp. 13-24, 2010.

[6] L. A. Van Meeteren, P. Ruurs, E. Christodoulou et al., "Inhibition of autotaxin by lysophosphatidic acid and sphingosine 1-phosphate," Journal of Biological Chemistry, vol. 280, no. 22, pp. 21155-21161, 2005.

[7] T. Sugiura, S. Nakane, S. Kishimoto, K. Waku, Y. Yoshioka, and A. Tokumura, "Lysophosphatidic acid, a growth factorlike lipid, in the saliva," Journal of Lipid Research, vol. 43, no. 12, pp. 2049-2055, 2002.

[8] M. Tanaka, Y. Kishi, Y. Takanezawa, Y. Kakehi, J. Aoki, and H. Arai, "Prostatic acid phosphatase degrades lysophosphatidic acid in seminal plasma," FEBS Letters, vol. 571, no. 1-3, pp. 197-204, 2004.

[9] A. Masuda, K. Nakamura, K. Izutsu et al., "Serum autotaxin measurement in haematological malignancies: a promising marker for follicular lymphoma," British Journal of Haematology, vol. 143, no. 1, pp. 60-70, 2008.

[10] K. Nakamura, M. Nangaku, R. Ohkawa et al., "Analysis of serum and urinary lysophospholipase D/autotaxin in nephrotic syndrome," Clinical Chemistry and Laboratory Medicine, vol. 46, no. 1, pp. 150-151, 2008.

[11] K. Nakamura, K. Igarashi, R. Ohkawa et al., "Autotaxin enzyme immunoassay in human cerebrospinal fluid samples," Clinica Chimica Acta, vol. 405, no. 1-2, pp. 160-162, 2009.

[12] S. Jansen, M. Andries, K. Vekemans, H. Vanbilloen, A. Verbruggen, and M. Bollen, "Rapid clearance of the circulating metastatic factor autotaxin by the scavenger receptors of liver sinusoidal endothelial cells," Cancer Letters, vol. 284, no. 2, pp. 216-221, 2009.

[13] M. Tanaka, S. Okudaira, Y. Kishi et al., "Autotaxin stabilizes blood vessels and is required for embryonic vasculature by producing lysophosphatidic acid," Journal of Biological Chemistry, vol. 281, no. 35, pp. 25822-25830, 2006.

[14] S. E. Alvarez, S. Milstien, and S. Spiegel, "Autocrine and paracrine roles of sphingosine-1-phosphate," Trends in Endocrinology and Metabolism, vol. 18, no. 8, pp. 300-307, 2007.

[15] H. Fyrst and J. D. Saba, "An update on sphingosine-1phosphate and other sphingolipid mediators," Nature Chemical Biology, vol. 6, no. 7, pp. 489-497, 2010.
[16] T. Clair, H. Y. Lee, L. A. Liotta, and M. L. Stracke, "Autotaxin is an exoenzyme possessing $5^{\prime}$-nucleotide phosphodiesterase/ATP pyrophosphatase and ATPase activities," Journal of Biological Chemistry, vol. 272, no. 2, pp. 996-1001, 1997.

[17] R. Gijsbers, J. Aoki, H. Arai, and M. Bollen, "The hydrolysis of lysophospholipids and nucleotides by autotaxin (NPP2) involves a single catalytic site," FEBS Letters, vol. 538, no. 13, pp. 60-64, 2003.

[18] L. A. van Meeteren and W. H. Moolenaar, "Regulation and biological activities of the autotaxin-LPA axis," Progress in Lipid Research, vol. 46, no. 2, pp. 145-160, 2007.

[19] J. Aoki, A. Inoue, and S. Okudaira, "Two pathways for lysophosphatidic acid production," Biochimica et Biophysica Acta, vol. 1781, no. 9, pp. 513-518, 2008.

[20] S. Okudaira, H. Yukiura, and J. Aoki, "Biological roles of lysophosphatidic acid signaling through its production by autotaxin," Biochimie, vol. 92, no. 6, pp. 698-706, 2010.

[21] K. Hama, K. Bandoh, Y. Kakehi, J. Aoki, and H. Arai, "Lysophosphatidic acid (LPA) receptors are activated differentially by biological fluids: possible role of LPA-binding proteins in activation of LPA receptors," FEBS Letters, vol. 523, no. 1-3, pp. 187-192, 2002.

[22] J. Lee, IN. D. Jung, S. W. Nam et al., "Enzymatic activation of autotaxin by divalent cations without EF-hand loop region involvement," Biochemical Pharmacology, vol. 62, no. 2, pp. 219-224, 2001.

[23] J. A. Boutin and G. Ferry, "Autotaxin," Cellular and Molecular Life Sciences, vol. 66, no. 18, pp. 3009-3021, 2009.

[24] S. Jansen, M. Andries, R. Derua, E. Waelkens, and M. Bollen, "Domain interplay mediated by an essential disulfide linkage is critical for the activity and secretion of the metastasispromoting enzyme autotaxin," Journal of Biological Chemistry, vol. 284, no. 21, pp. 14296-14302, 2009.

[25] E. Koh, R. W. Bandle, D. D. Roberts, M. L. Stracke, and T. Clair, "Novel point mutations attenuate autotaxin activity," Lipids in Health and Disease, vol. 8, article no. 4, 2009.

[26] L. A. Van Meeteren, P. Ruurs, C. Stortelers et al., "Autotaxin, a secreted lysophospholipase D, is essential for blood vessel formation during development," Molecular and Cellular Biology, vol. 26, no. 13, pp. 5015-5022, 2006.

[27] JI. W. Choi, C. W. Lee, and J. Chun, "Biological roles of lysophospholipid receptors revealed by genetic null mice: an update," Biochimica et Biophysica Acta, vol. 1781, no. 9, pp. 531-539, 2008.

[28] S. Liu, M. Umezu-Goto, M. Murph et al., "Expression of autotaxin and lysophosphatidic acid receptors increases mammary tumorigenesis, invasion, and metastases," Cancer Cell, vol. 15, no. 6, pp. 539-550, 2009.

[29] M. L. Stracke, H. C. Krutzsch, E. J. Unsworth et al., "Identification, purification, and partial sequence analysis of autotaxin, a novel motility-stimulating protein," Journal of Biological Chemistry, vol. 267, no. 4, pp. 2524-2529, 1992.

[30] M. Umezu-Goto, Y. Kishi, A. Taira et al., "Autotaxin has lysophospholipase D activity leading to tumor cell growth and motility by lysophosphatidic acid production," Journal of Cell Biology, vol. 158, no. 2, pp. 227-233, 2002.

[31] C. G. Gaetano, N. Samadi, J. L. Tomsig, T. L. Macdonald, K. R. Lynch, and D. N. Brindley, "Inhibition of autotaxin production or activity blocks lysophosphatidylcholine-induced migration of human breast cancer and melanoma cells," Molecular Carcinogenesis, vol. 48, no. 9, pp. 801-809, 2009.

[32] M. K. Altman, V. Gopal, W. Jia et al., "Targeting melanoma growth and viability reveals dualistic functionality of the 
phosphonothionate analogue of carba cyclic phosphatidic acid," Molecular Cancer, vol. 9, article no. 140, 2010.

[33] A. D. Singh, K. Sisley, Y. Xu et al., "Reduced expression of autotaxin predicts survival in uveal melanoma," British Journal of Ophthalmology, vol. 91, no. 10, pp. 1385-1392, 2007.

[34] K. Hama, J. Aoki, M. Fukaya et al., "Lysophosphatidic acid and autotaxin stimulate cell motility of neoplastic and nonneoplastic cells through LPA," Journal of Biological Chemistry, vol. 279, no. 17, pp. 17634-17639, 2004.

[35] H. Y. Lee, G. U. Bae, IN. D. Jung et al., "Autotaxin promotes motility via $G$ protein-coupled phosphoinositide 3-kinase $\gamma$ in human melanoma cells," FEBS Letters, vol. 515, no. 1-3, pp. 137-140, 2002.

[36] IN. D. Jung, J. Lee, S. Y. Yun et al., "Cdc42 and Rac1 are necessary for autotaxin-induced tumor cell motility in A2058 melanoma cells," FEBS Letters, vol. 532, no. 3, pp. 351-356, 2002.

[37] IN. D. Jung, J. Lee, K. B. Lee et al., "Activation of p21-activated kinase 1 is required for lysophosphatidic acid-induced focal adhesion kinase phosphorylation and cell motility in human melanoma A2058 cells," European Journal of Biochemistry, vol. 271, no. 8, pp. 1557-1565, 2004.

[38] J. Lee, I. D. Jung, C. G. Park, J. W. Han, and H. Y. Lee, "Autotaxin stimulates urokinase-type plasminogen activator expression through phosphoinositide 3-kinase-Akt-necrosis factor kappa B signaling cascade in human melanoma cells," Melanoma Research, vol. 16, no. 5, pp. 445-452, 2006.

[39] E. Gendaszewska-Darmach, "Lysophosphatidic acids, cyclic phosphatidic acids and autotaxin as promissing targets in therapies of cancer and other diseases," Acta Biochimica Polonica, vol. 55, no. 2, pp. 227-240, 2008.

[40] T. Clair, E. Koh, M. Ptaszynska et al., "L-histidine inhibits production of lysophosphatidic acid by the tumor-associated cytokine, autotaxin," Lipids in Health and Disease, vol. 4, article 5, 2005.

[41] D. L. Bakera, Y. Fujiwara, K. R. Pigg et al., "Carba analogs of cyclic phosphatidic acid are selective inhibitors of autotaxin and cancer cell invasion and metastasis," Journal of Biological Chemistry, vol. 281, no. 32, pp. 22786-22793, 2006.

[42] G. D. Prestwich, J. Gajewiak, H. Zhang, X. Xu, G. Yang, and M. Serban, "Phosphatase-resistant analogues of lysophosphatidic acid: agonists promote healing, antagonists and autotaxin inhibitors treat cancer," Biochimica et Biophysica Acta, vol. 1781, no. 9, pp. 588-594, 2008.

[43] A. Uchiyama, M. Mukai, Y. Fujiwara et al., "Inhibition of transcellular tumor cell migration and metastasis by novel carba-derivatives of cyclic phosphatidic acid," Biochimica et Biophysica Acta, vol. 1771, no. 1, pp. 103-112, 2007.

[44] G. Jiang, Y. Xu, Y. Fujiwara et al., “ $\alpha$-substituted phosphonate analogues of lysophosphatidic acid (LPA) selectively inhibit production and action of LPA," ChemMedChem, vol. 2, no. 5, pp. 679-690, 2007.

[45] Y. Fujiwara, "Cyclic phosphatidic acid-a unique bioactive phospholipid," Biochimica et Biophysica Acta, vol. 1781, no. 9, pp. 519-524, 2008.

[46] H. M. H. G. Albers, A. Dong, L. A. Van Meeteren et al., "Boronic acid-based inhibitor of autotaxin reveals rapid turnover of LPA in the circulation," Proceedings of the National Academy of Sciences of the United States of America, vol. 107, no. 16, pp. 7257-7262, 2010.

[47] J. Gierse, A. Thorarensen, K. Beltey et al., "A novel autotaxin inhibitor reduces lysophosphatidic acid levels in plasma and the site of inflammation," Journal of Pharmacology and Experimental Therapeutics, vol. 334, no. 1, pp. 310-317, 2010.
[48] L. P. Saunders, A. Ouellette, R. Bandle et al., "Identification of small-molecule inhibitors of autotaxin that inhibit melanoma cell migration and invasion," Molecular Cancer Therapeutics, vol. 7, no. 10, pp. 3352-3362, 2008.

[49] A. B. Hoeglund, A. L. Howard, I. W. Wanjala, T. C. T. Pham, A. L. Parrill, and D. L. Baker, "Characterization of non-lipid autotaxin inhibitors," Bioorganic and Medicinal Chemistry, vol. 18, no. 2, pp. 769-776, 2010.

[50] A. B. Hoeglund, H. E. Bostic, A. L. Howard et al., "Optimization of a pipemidic acid autotaxin inhibitor," Journal of Medicinal Chemistry, vol. 53, no. 3, pp. 1056-1066, 2010.

[51] K. Ueda, M. Yoshihara, M. Nakao et al., "Evaluation of inhibitory actions of flavonols and related substances on lysophospholipase D activity of serum autotaxin by a convenient assay using a chromogenic substrate," Journal of Agricultural and Food Chemistry, vol. 58, no. 10, pp. 60536063, 2010.

[52] J. E. Day, T. Hall, L. E. Pegg, T. E. Benson, J. Hausmann, and S. Kamtekar, "Crystallization and preliminary X-ray diffraction analysis of rat autotaxin," Acta Crystallographica Section F, vol. 66, no. 9, pp. 1127-1129, 2010.

[53] J. Hausmann, E. Christodoulou, M. Kasiem et al., "Mammalian cell expression, purification, crystallization and microcrystal data collection of autotaxin/ENPP2, a secreted mammalian glycoprotein," Acta Crystallographica Section F, vol. 66, no. 9, pp. 1130-1135, 2010. 

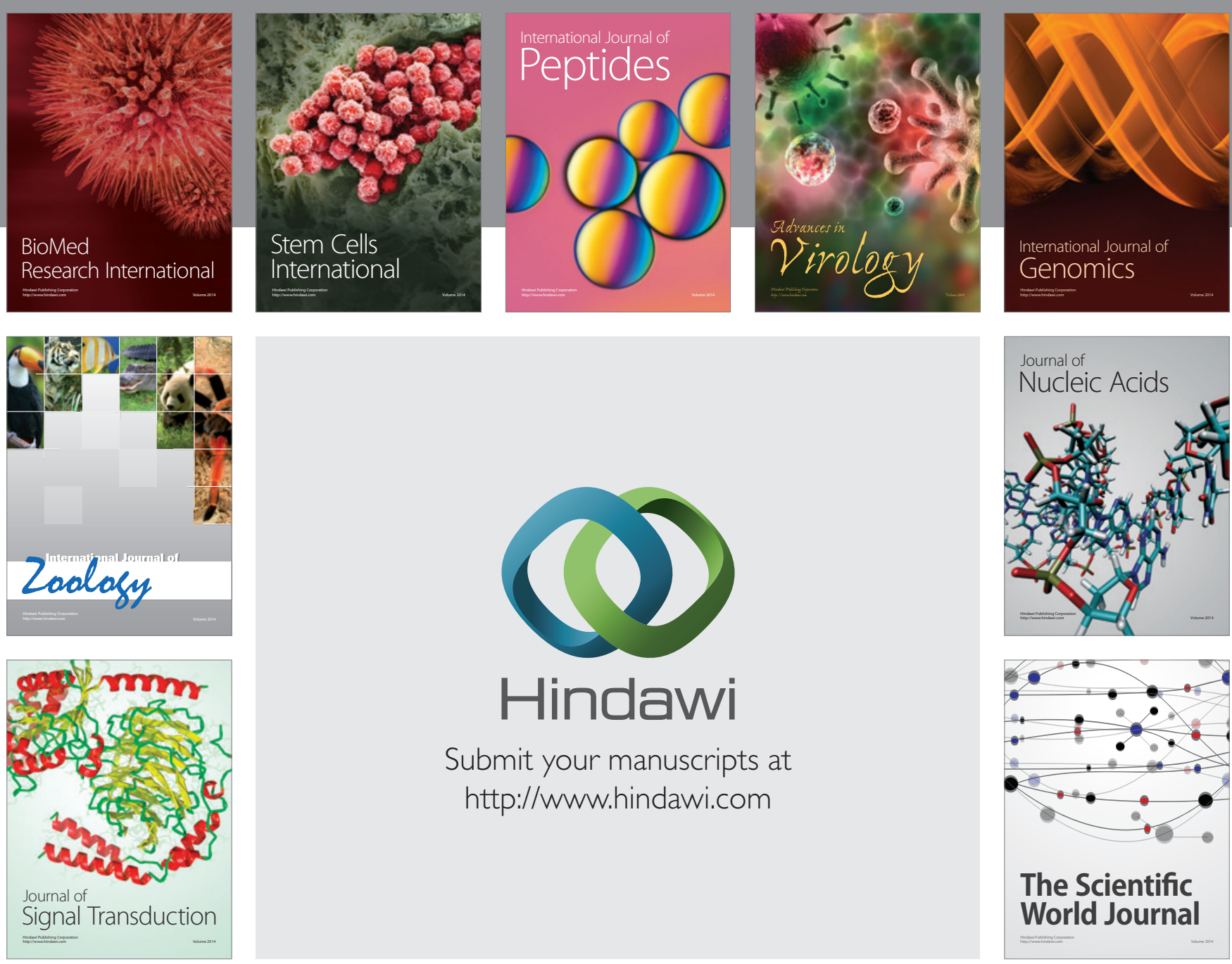

Submit your manuscripts at

http://www.hindawi.com
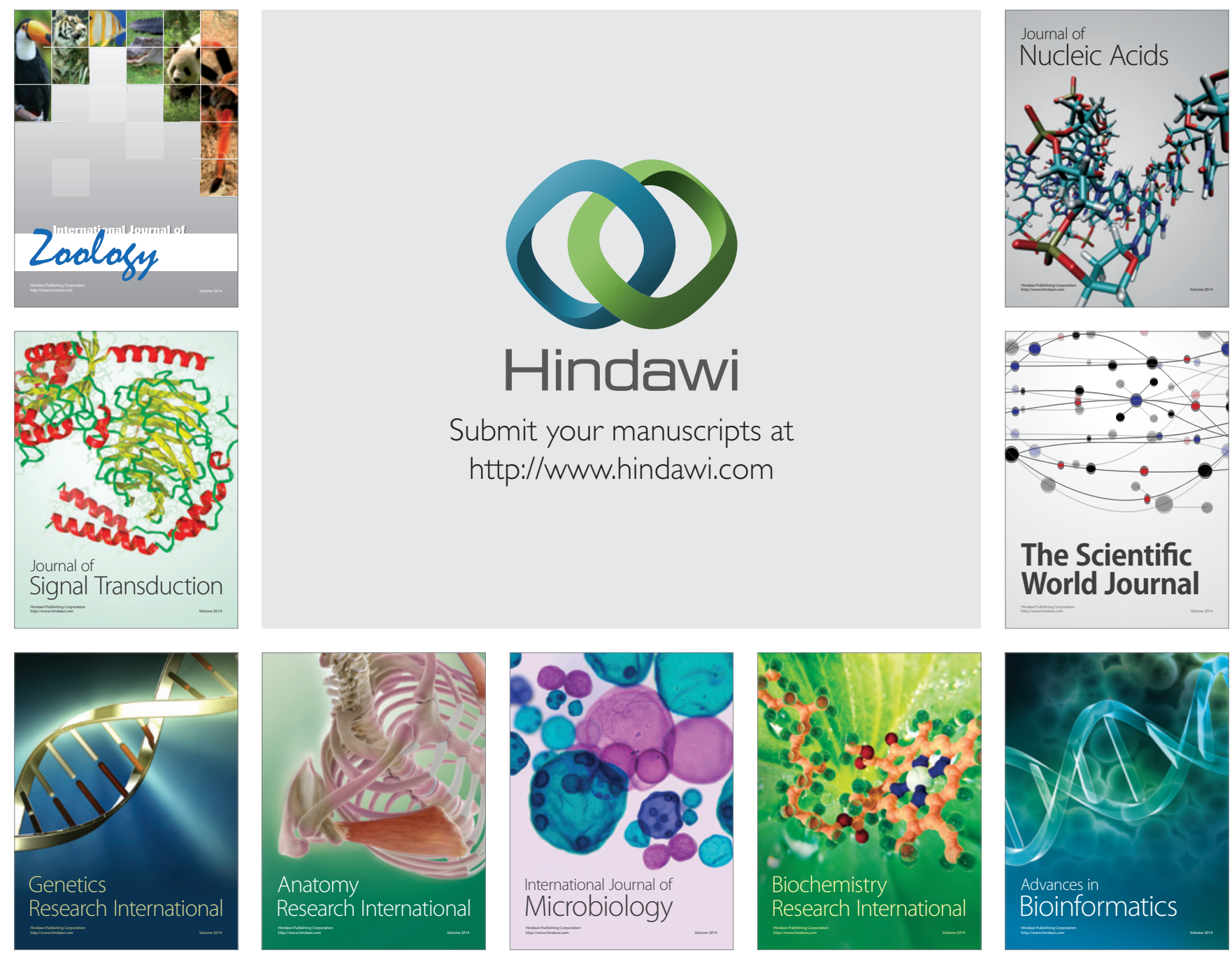

The Scientific World Journal
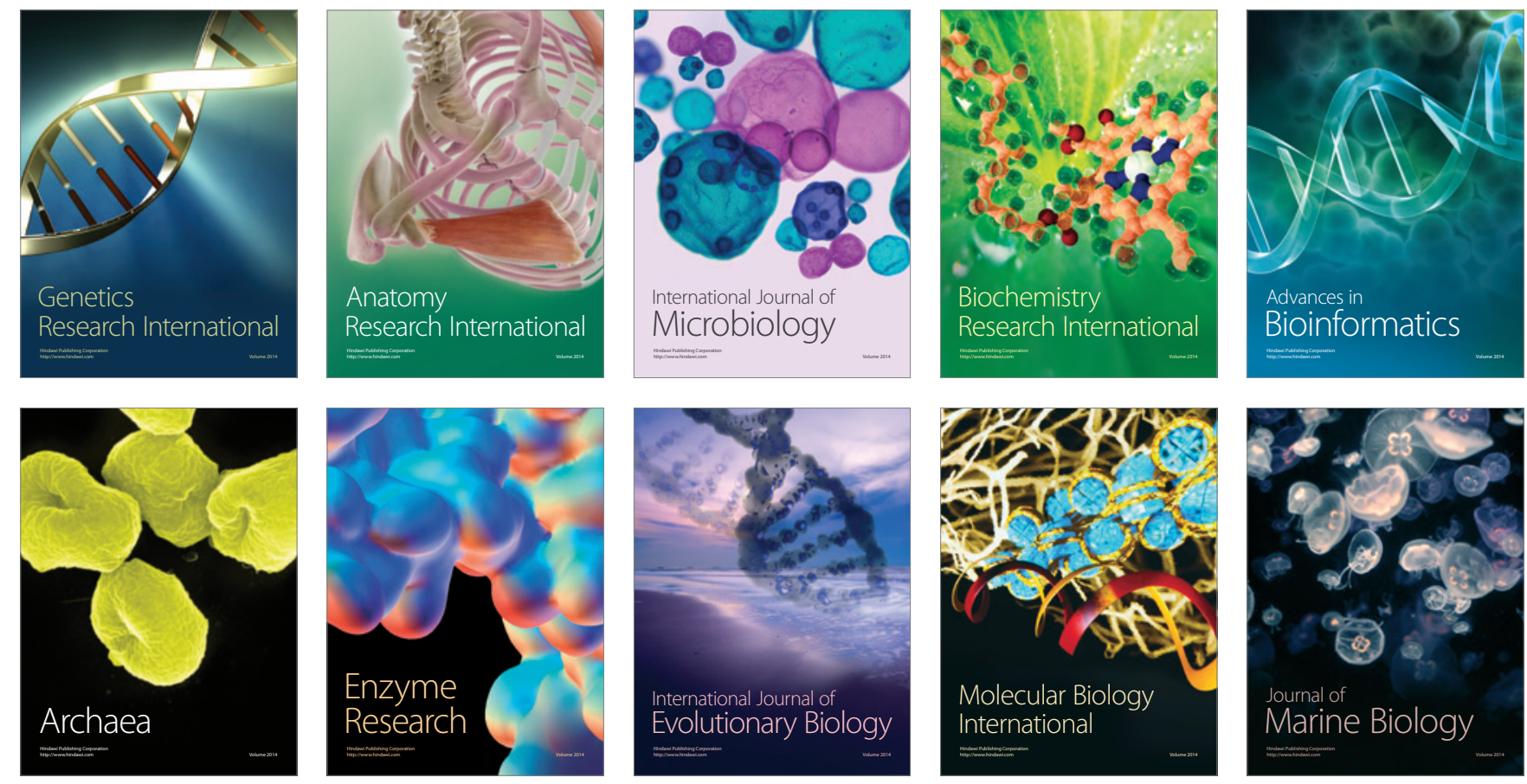